\title{
Combining Knowledge Systems Helps Understand the Spatial Dynamics of Data-Limited Small-Scale Fisheries Systems in Brazil: A Methods Analysis
}

\author{
Rebecca Borges $1,2 *$, Indira A. L. Eyzaguirre ${ }^{3}$, Roberta Sá Leitão Barboza ${ }^{2}$, Karin Boos ${ }^{4}$, \\ Marion Glaser ${ }^{5,6}$ and Priscila F. M. Lopes ${ }^{7}$ \\ ${ }^{1}$ Faculty of Biology/Chemistry, University of Bremen, Bremen, Germany, ${ }^{2}$ Laboratório de Ensino, Pesquisa e Extensão \\ Pesqueira de Comunidades Amazônicas (LABPEXCA), Universidade Federal do Pará, Bragança, Brazil, ${ }^{3}$ Laboratório de \\ Ecologia de Manguezal (LAMA), Universidade Federal do Pará, Bragança, Brazil, ${ }^{4}$ Thuenen Institute of Sea Fisheries, \\ Bremerhaven, Bremen, Germany, ${ }^{5}$ Leibniz Centre for Tropical Marine Research (ZMT), Bremen, Germany, ${ }^{6}$ Institute of \\ Geography, University of Bremen, Bremen, Germany, ${ }^{7}$ Fishing Ecology, Management and Economics Group, Department of \\ Ecology, Universidade Federal do Rio Grande do Norte, Natal, Brazil
}

OPEN ACCESS

Edited by: John A. Cigliano,

Cedar Crest College, United States

Reviewed by: Maria Inês Paes Ferreira, Instituto Federal Fluminense, Brazil Yiping Ren,

Ocean University of China, China

*Correspondence: Rebecca Borges rebecca.borges@uni-bremen.de

Specialty section: This article was submitted to Marine Conservation and Sustainability, a section of the journal

Frontiers in Marine Science

Received: 18 August 2021

Accepted: 28 October 2021

Published: 01 December 2021

Citation:

Borges $R$, Eyzaguirre IAL Sá Leitão Barboza R, Boos K, Glaser M and Lopes PFM (2021) Combining Knowledge Systems Helps Understand the Spatial

Dynamics of Data-Limited Small-Scale Fisheries Systems

in Brazil: A Methods Analysis.

Front. Mar. Sci. 8:760535. doi: 10.3389/fmars.2021.760535
Mangrove habitats provide nursery, shelter, and feeding sites for many economically relevant fish, and invertebrates, such as crabs. Given the highly artisanal character and the patchy spatial distribution of small-scale fishing in mangroves, there is often little data available to inform management, potentially threatening the sustainability of this livelihood-supporting activity. This study assesses the combination of different data collection methods and of including published data in the analysis of the spatial dynamics. We examine crab fisheries in two sustainable-use protected areas as a case study to understand use patterns as indicated by a specific combination of mapping methods. Mangrove crab fishing grounds were mapped by overlaying crab gatherers' tracked routes with maps produced during participatory-mapping-centered interviews. Information from the literature was used to spatialize crab carapace width and relate it to distance traveled by fishers. Results show that crabs tended to be larger if caught farther from the villages where fishers live. In terms of collection methods, even though GPS tracking is relatively time- and resource-consuming, incorporating some GPS tracking into participatory mapping helps overcome a downside of this type of mapping (e.g., lack of geographical precision) and identifies information that can be accessed through participatory techniques. This highlights the importance of linking different approaches in order to understand small-scale fisheries spatial dynamics.

Keywords: marine protected areas, participatory mapping, mangroves, fishing grounds, fishers' territories, GPS tracking, fisheries spatial management

\section{INTRODUCTION}

Small-scale fisheries are mainly associated with and known to support subsistence production (Hall et al., 2013) and are often responsible for food security in local communities which strongly depend on mangrove ecosystems (Glaser, 2003; UNEP, 2014). Mangroves also sustain invertebrate and fish species that are directly fished or consumed by other organisms that are then fished by humans 
(Nagelkerken et al., 2008), sustaining small-scale fisheries and food security of vulnerable human populations (Spalding et al., 2010). However, fish stocks have been collapsing in many systems, with impacts on ecosystem stability, biodiversity, and livelihoods (Worm et al., 2006, 2009). Similarly, mangroves have been disappearing, with losses of $35 \%$ of area in some parts of the world, largely attributable to human activities (Valiela et al., 2001). These negative trends might still be reversible (Worm et al., 2006; Fulton et al., 2019), and protected areas (PAs) are widely advertised as a tool to restore these depleted resources (Worm et al., 2009; Vandeperre et al., 2011; UNEP, 2014; Campos-Silva and Peres, 2016). For this, careful consideration is needed of the role these ecosystems and the resources they provide play for livelihood support in order to help conserve fishery resources in mangroves (UNEP, 2014).

The establishment of reserves does not, however, necessarily solve the widespread lack of data in small-scale fisheries worldwide, in terms of landing and stock assessment data (Mills et al., 2011), and data for social-ecological assessments (Kittinger, 2013), which hinders adequate management. In Brazil, for example, there has been no official monitoring of smallscale fisheries for over 10 years (Sganzerla, 2017). To fill the resulting information gaps in fisheries, innovative, timeeffective, and affordable approaches for data collection and synthesis are needed. Participatory mapping and GPS tracking of fishing activities are candidate examples of such approaches. Participatory mapping can help establish a basis for the management of resources through knowledge and values if local (indigenous, traditional, fishers, etc.) and technical knowledge systems are integrated as equally relevant for management design (Silvano and Valbo-Jørgensen, 2008). GPS tracking has recently been used for small-scale fisheries (Pennino et al., 2016; Metcalfe et al., 2017), so the potential of this method has only started to be accessed.

In addition to investigating the different methods separately, some mixing and matching of usual collection methods (e.g., information from participatory mapping and technical data from landing surveys) and the integration of different knowledge systems, e.g., local ecological knowledge and technical (or "scientific") knowledge, have also been previously studied. For example, an overlap has been identified between Brazilian fishers' perceptions and official landing data, but mainly for species that are relatively abundant in the catch (Damasio et al., 2015). In the Solomon Islands, surveys on local perceptions and visual census of a pivotal coral fish species were used to complement investigations of the species' associated habitats and its need for protection, as well as in identifying contexts where local participation and successful conservation outcomes are more likely (Aswani and Hamilton, 2004). The spatial dynamics of migrant fishers was investigated in Kenya using a combination of participatory mapping and GPS tracking of vessels. The results from each method were analyzed comparatively and complementarily (Wanyonyi et al., 2018).

For the Brazilian mangrove belt, for example, GPS and participatory mapping have been combined to investigate spatial dynamics of the fisheries of the mangrove crab (Ucides cordatus L.) (Thies-Albrecht, 2016). Drawing on these investigations, this study examines the information that can be obtained by contrasting and merging data from participatory mapping and GPS tracking into one dataset. This study specifically investigates how local and technical knowledge can be systematically integrated for local level ecosystem-based management. Policy recommendations are offered to safeguard the sustainability of the crab fisheries in northern Brazilian mangroves. This study was led by two research questions:

1. What kind of spatial data on small-scale fishing grounds can be generated with a combination of participatory mapping and GPS tracking?

2. What are the advantages and disadvantages of spatializing fishing grounds by merging participatory mapping and GPS tracking data?

As an example of how to combine the two data collection methods, we analyze the patterns of resource use within and between two adjacent PAs in Brazilian coastal Amazonia and investigate the correlation between two variables: distance from home village to fishing ground and crab size. Due to the methodological nature of this study, less attention is given to the particular characteristics of the local fisheries and specific patterns drawn from the results. Also, the methods are already compared in section "Results," including a brief discussion with a previous study done in the region, which was an essential one to the formulation of the methods presented here.

\section{MATERIALS AND METHODS}

\section{Study Area}

The study area encompasses mangroves and nearby waters in two sustainable-use areas in the municipalities of Tracuateua and Bragança, northern Brazil (Figure 1).

The Bragança coastal plain is situated in the northeastern part of Pará State $\left(00^{\circ} 46^{\prime}-1^{\circ} 00^{\prime} \mathrm{S}\right.$ and $\left.46^{\circ} 36^{\prime}-46^{\circ} 44^{\prime} \mathrm{W}\right)$ (Cohen et al., 2004). The Tracuateua coastal plain is located west of Bragança $\left(00^{\circ} 46^{\prime} \mathrm{S}\right.$ and $\left.47^{\circ} 10^{\prime} \mathrm{W}\right)$. Bragança hosts a mangrove forest of about $180 \mathrm{~km}^{2}$ (Souza-Filho and Paradella, 2002; SouzaFilho et al., 2006), while Tracuateua exhibits mangroves of about $90 \mathrm{~km}^{2}$, according to the calculations based on data by Giri et al. (2011).

The Bragantina Peninsula is part of the largest range of mangroves in the world (Nascimento et al., 2013; Hayashi, 2018; Diniz et al., 2019) where the extraction of the mangrove crab is important for this region, being its main source of income for $38 \%$ of the population (Glaser, 2003). In Bragança alone, there are approximately 57 communities that depend on artisanal fishing, including crab (Abdala et al., 2012). The dependence relationship includes extractive activities and family-based farming (do Vale Oliveira and de Brito Alves, 2021). Approximately 67\% of the population of estuarine-coastal communities are part of the crab production network (Oliveira et al., 2017). The communities that practice artisanal fishing in Bragança live around the mangroves and use the crab as a source of income and food (Costa et al., 2013). Between 2003 and 2004, the municipality of Bragança had 1195 crab fishers, who transported in small boats, canoes, 

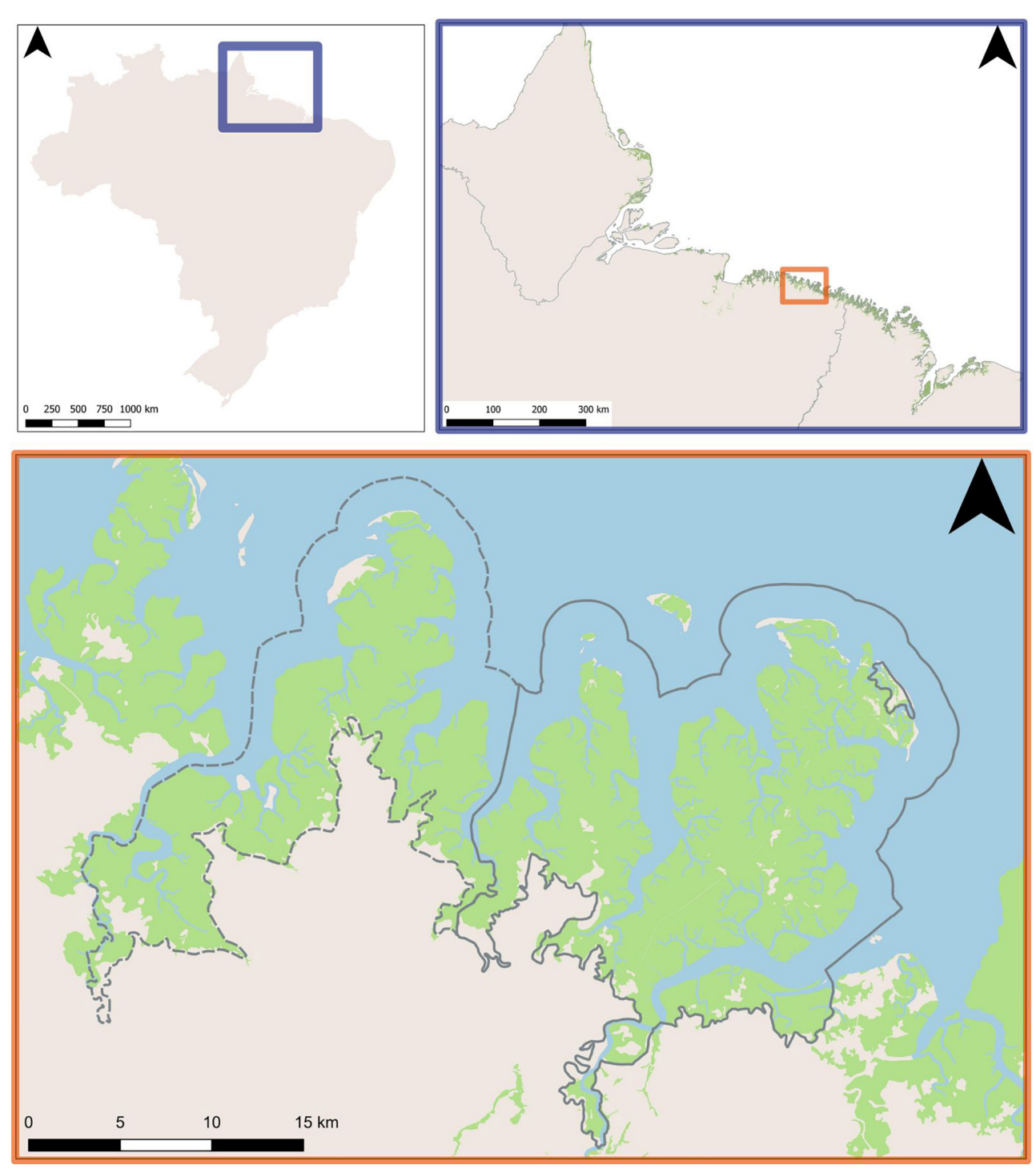

FIGURE 1 | Study area with the delimitations of the two protected areas, Tracuateua (west) and Bragança (east). Together they have 270 km² of mangrove area, which corresponds to approximately $40 \%$ of the total area of these two reserves.

and on foot through the mangrove swamp (da Rocha Araújo, 2006). For example, in 2004, Bragança obtained 1002.88 tons of crab production (ICMBio, 2004). For many communities, crab fishing represents the source of income for more than half of the population (Glaser, 2003). Bragança has a large influence on local villages and nearby cities. A number of people from the surrounding area go to sell and buy products like flour and crabs and manufactured goods in Bragança's markets (Partelow et al., 2018).

The organization of marketing and work opportunities drives the intensification of crab (Maneschy, 2003), which started in the early 2000s in Bragança (da Rocha Araújo, 2006). Crab fishing has evolved from a sporadic activity to a main subsistence activity for many communities, increasing the complexity of its production chain (Magalhães et al., 2007; Domingues, 2008). The processing of crab meat has become a key element in this chain that includes the work of women in this production process (Partelow et al., 2018). For example, in Vila do Treme, the processing of the mangrove crab started as a subsistence activity and evolved into a main economic activity (Magalhães et al., 2007). This processing consists of removing the meat from a cooked crab, packaging it and freezing it for later sale (Ogawa et al., 2008). Fished crabs can be sold, processed or in natura, to cities all over the country, including Belém, Fortaleza, and São Paulo $(210$ km, 1325 km, and $2900 \mathrm{~km}$ away from Bragança by road, respectively) (Borges, 2020; Gomes, 2018). In the crab value chain, middlemen can have a profit that is up to eight times larger than that of primary producers (crab fishers) (Gomes, 2018).

For the purposes of this study, small-scale fisheries, although spatially and temporally diverse, are characterized by the 
use of simple means of transportation, low-technology equipment, narrow geographical range, and a reliance on local knowledge for harvest strategies. For further discussions on issues around the definition of small-scale fisheries, refer to Smith and Basurto (2019).

\section{Datasets}

The analyses were based on data collected through participatory mapping and GPS tracking and on a combination of these results with those published in the scientific literature.

\section{Data From Participatory Mapping}

Semi-structured interviews and workshops were conducted with local stakeholders, including fishers, community leaders, scholars, and local authorities. Throughout this paper, the word "fisher" is used to designate crab collectors, those women or men who go to the mangrove forest to harvest the crabs, but not the users down the value chain, such as those working on crab meat processing or sales.

During the first phase of interviews (October 2016 to January 2017), 78 participants were asked to identify important areas for the crab fisheries, i.e., fishing grounds and the villages where the fishers who use each mangrove area live. During the second phase of interviews (November 2017 to March 2018), most informants were revisited $(n=57)$ and presented with the resulting maps from the first phase. Participatory mapping activities were performed during the dry season because the temporal closures of crab fishing take place during the wet season, when the fishers become fearful of monitoring and are less willing to share information. In the interviews, fishers would talk about general trends, neither focusing on the dry nor wet season.

Informants for all field work phases were selected based on previous studies and the snowball method (Goodman, 1961). Participants' villages were grouped according to their formal association with one of our two PAs, i.e., in which they would be recognized as users and granted access to use its natural resources. Users are locally acknowledged to be inhabitants of the PA (including its buffer zone) who are directly dependent on the small-scale, low-impact (artisanal) extraction of mangrove or aquatic resources in the PA (Abdala et al., 2012). The Bragança PA has a larger population (IBGE, 2019a) and, therefore, a larger number of users (IBGE, 2019a,b). For this reason, the sampling size was larger for the Bragança PA.

Large print maps of the study area were used to facilitate the spatial referencing process. By including commonly used place names and symbols related to local activities and landmarks, the maps were designed to ensure maximum participation from interviewees and effectiveness of sampled results. The maps prompted informants to talk about geographic places, their locally given names, and how these places are visited, even though informants were not used to being interviewed with maps. This labeling of places on the maps helped the interviewees to locate the fishing grounds on the maps presented to them.

For the second phase, focus group interviews were conducted to stimulate discussions about the results of Phase I. To prevent some informant's opinions from dominating the mapping exercise, no focus group had more than 2-3 people and the facilitators (R.B. and fieldwork collaborators) tried to stimulate discussion among all of them. However, it is important to notice that apparent conformity of view is an emergent property of the group interaction, not a reflection of individual participants' opinions, because less-confident members of the group may not express alternative points of view, and the moderator might assume that they agree with the prevailing view (Sim, 1998). Usually, the more homogeneous the group, the more likely they are to voice their opinions (Sim, 1998). Therefore, homogeneous groups were formed regarding profession (fishers, administration employees, etc.) and, in the case of direct users (i.e., local inhabitants that extract from mangroves natural resources such as crabs, fish, and wood), the village of origin, so that conflicts were avoided and informants could feel more comfortable sharing information. For the focus groups and workshops, no differentiation was made about which informant is saying what, i.e., information is considered to come from the group and not from single individuals, since the participants tended to reach an agreement. Informants' opinions on the maps, including new information, suggestions, and corrections were used to fine-tune the analyses. Consensus was not pursued, but rather a wide range of perceptions, independently of whether all informants agreed with them or not, even though this might have led to the inclusion of data that is not, at least presently, accurate.

For both rounds of interviews, the information from the participatory mapping was digitalized using the free and open-source GIS application QGIS 3.4 (Quantum GIS Development Team, 2019). The coordinate reference system SIRGAS 2000/UTM zone 23S, EPSG 31983 was used. Fishing grounds were digitalized based on how they had been drawn or orally described by the informants. After the second phase of interviews, a standardized delimitation of the fishing grounds was performed, by combining the place names and degrees of geographical specification provided by the informants, with the information from ground-truthing and previously published maps.

During the participatory mapping exercise, fishing grounds were delineated based on two main criteria: (1) the names given by the informants to the places where fishers went fishing and (2) the continuous mangrove area that roughly corresponded to where the fishing ground was reported to be located. This last criterion was largely based, therefore, on the mangrove distribution shapefile used in this study (Giri et al., 2011). This means that the delineation of the fishing grounds was heavily influenced by the shapefile used to digitalize the information provided by the fishers.

For the analyses presented here, the GPS tracking method generated "technical" (sometimes referred to as "scientific") data, while the participatory mapping provided local user knowledge, based on everyday experience. Even though the GPS tracking data can be considered "technical," participant fishers might have, consciously or inadvertently, influenced the sampling of the routes, not only in terms of choosing where to go while they were carrying the GPS but also when to take it with them. For instance, some crab fishers were unwilling to take the GPS during the months of January to April, because the temporal closure takes place during some days during these months. Fishers were, 
at times, unwilling to participate during these months, even on days outside the temporal closure.

\section{Data From GPS Tracking}

Fishing routes were tracked from November 2017 to February 2019. GPS tracker ("GT-750FL Bluetooth GPS Receiver") distribution among crab fishers was done systematically in terms of transportation means, covering at least one fisher per type of transportation means in a given village. The largest villages were selected, as well as small ones where the crab fisheries are known to be an important activity for local livelihoods.

\section{Data From the Literature}

In order to obtain a match between fishing grounds used and crab size in each fishing ground, the data from the interviews in this study were combined with data from a previous study (Oliveira, 2015), which measured crab carapace width in the mangroves of Bragança.

\section{Reconstruction of Traveled Routes}

Using QGIS, fishing routes were "reconstructed" in order to calculate more realistic distances to fishing grounds. In this study, reconstruction means estimating the routes taken by fishers when they only mentioned, during the participatory mapping, the origin (home village) and destination (fishing ground) of their fishing movements. In order to reconstruct the fishing routes and calculate traveled distances, informants and collaborating fishers were asked about different transportation means used by all crab fishers in each fishing village analyzed (Table 1).

GPS tracked routes also had to be partially reconstructed because (1) either the way to or the way back from the fishing ground had to be chosen, in which case the shortest path was selected; and (2) a few of them were incomplete. The latter were only reconstructed, however, when the missing portion referred to the initial or final part of the trip and could be reasonably

TABLE 1 | Transportation means preferred by each crab fishing village in the Bragança and Tracuateua PAs, according to the interviews and surveys.

\begin{tabular}{lll}
\hline Village & Municipality & Means of transportation used \\
\hline Quatipuru & Tracuateua & Canoe with engine \\
Tamatateua & Bragança & Canoe with engine \\
Caratateua & Bragança & Canoe with engine or boat \\
Mimi & Tracuateua & Bicycle + canoe \\
Treme & Bragança & On foot, canoe with engine, or boat \\
Sessenta & Tracuateua & On foot or motorcycle \\
America & Bragança & Bicycle + bus or canoe \\
Chapada & Tracuateua & On foot or canoe \\
Flexeira & Tracuateua & On foot, canoe with engine, or bicycle \\
Vila Cuera & Bragança & On foot or canoe with engine \\
Tacuandeua & Bragança & Canoe with engine \\
Pontinha & Bragança & Canoe with engine or boat \\
Acarajó & Bragança & Car, bus, or bicycle \\
Cajueiro & Bragança & On foot or boat \\
Nanam & Tracuateua & Bicycle \\
Patalino & Bragança & Car \\
& &
\end{tabular}

estimated. (Fishers would at times forget to turn on the GPS tracker until they were already halfway through the trip to the fishing ground, or would turn them off before they reached their home village.)

The following criteria were used to construct a plausible path, based on information provided by fishers during the interviews and on previous studies:

I. Fishers use the means of transportation they mentioned in the surveys (Table 1);

II. Fishers avoid including paths that are "deep" into the mangroves because these are areas where movement is made difficult by the mangrove roots and the muddy substrate;

III. Fishers avoid what they call "river mouths" (where rivers widen, near the tips of the peninsulas);

IV. Fishers travel by boat or canoe, preferably along the shores;

V. Fishers take well-known channels (locally known as "furos"). These channels were identified either by previous ground-truthing (e.g., boat trips) or by satellite imagery;

VI. Fishers prefer to travel by water, except otherwise mentioned;

VII. Fishers avoid entering or passing by other villages;

VIII. When traveling by boat or canoe, fishers leave from the local port;

IX. When the fishing ground is relatively close, fishers prefer to go on foot;

X. For further aspects, previous work (e.g., Thies-Albrecht, 2016) was consulted.

\section{Distances to Fishing Grounds}

One-way distances from the fishers' village to their fishing grounds were calculated. Distance traveled was chosen as a measure of effort, since it directly related to time and fuel consumed. Also, in preliminary conversations, local fishers mentioned that they had recently observed an increase in distance traveled, the higher costs of which were compensated by larger (better-priced) catch crab sizes. The two collection methods (GPS tracking and participatory mapping) were compared in terms of distance traveled to check if both methods provided similar information. The two PAs were compared in terms of different distances traveled by fishers to their fishing grounds.

\section{Distances to Fishing Grounds and Crab Size}

Crab carapace width was used as a proxy for crab size, and inter- and extrapolation of crab carapace width following the methods in Oliveira (2015), for the Bragança PA. Since Oliveira's study focused on Bragança, the distance vs. crab size analysis was performed only for this PA.

Oliveira (2015) measured crab carapace width in 32 different points. This author then used the mean value for each point to spatialize carapace width (as a proxy for crab size) performing the analysis "Inverse Distance Weighted" in QGIS.

The mean crab carapace width shown in Oliveira (2015) was spatialized and used to perform a similar GIS analysis to obtain the spatialized values of width. Oliveira (2015) does not present the exact parameters used for this GIS analysis. Therefore, 
the parameters "distance coefficient" and "number of columns and rows" were calibrated to 2 and 300, in order to obtain similar results, as visualized on the map generated by Oliveira (2015). This author does not offer the numerical results from this operation but he provides a final map, which was compared to the map generated by this study. A visual assessment shows that (Oliveira, 2015) and this study obtained comparable results for this spatialization of crab size. It is not possible to compare the spatialized sizes obtained by Oliveira (2015) with those presented here, since while this author confirms the general trend of larger crabs in hard-to-access sites, (s)he does not present detailed numbers (Oliveira, 2015).

\section{Statistical Analyses}

To test the effect of the methods, GPS tracking and participatory mapping, on the respective distances, a linear model with Gaussian error terms was applied. The sample sizes for this analysis were 17 and 112, for GPS tracking and participatory mapping, respectively.

In addition, a fully crossed model with Gaussian error terms was applied to test for the effects of these methods and of the crab carapace width as a covariate on the distances traveled. The sample sizes for this analysis were 11 and 92, for GPS tracking and participatory mapping, respectively. Sample sizes were smaller for this analysis because, as explained before, crab sizes were available only for the Bragança PA, so that distances traveled within the Tracuateua PA were eliminated.

Prior to both analyses, the data were log-transformed to meet the assumptions of normal distribution and homogeneous variances of the residuals (checked through visual inspection of QQ plots of the residuals and scatterplots of the fitted data plotted against the residuals). The models were fitted in $\mathrm{R}$, version 3.5.3, using the generic function "lm." Because the datasets are highly unbalanced (more data points for participatory mapping than for GPS tracking), the following diagnostics of model stability were checked: leverage (Quinn and Keough, 2002) and Cook's distance and dffits (Cohen and Cohen, 2008), where data points are excluded one by one from the data sets and the respective fitted values are compared with those obtained from the model based on all data points. The checks (Cooks distance and dffits) confirmed that there are no influential cases. When checking the leverage, however, some influential deviations in both models were detected. These instabilities are likely to be due to the unbalanced dataset and were therefore accepted. The results were, therefore, interpreted with caution.

Significances of individual terms (interaction term and main factors) were established with likelihood ratio tests (LRTs) using the R function "anova" with the argument "test" set to "F." Hereby, the full model was tested against the corresponding reduced models without the respective factor and/or term of interest.

\section{Research Authorization and Ethics Statement}

The research was approved by ICMBio (Sisbio process number 36427147) and followed the Code of Ethics and procedures adopted by Brazilian universities as of 2015. Accordingly, participants in the study, including informants and fishers carrying GPS devices, were informed about the purpose of the questionnaire as well as data use and diffusion. We obtained oral consent from participants prior to conducting surveys and from GPS carriers before their fishing trips. Answers were recorded anonymously, and individual informants cannot be identified in published material or other publicly available records. Whenever possible and agreed upon by informants, we recorded personal contact information to facilitate the restitution of results to participants. This restitution activity started with the awarenessraising project funded by the Rufford Foundation (20310-1) and continues today, following the conclusion of the project.

\section{RESULTS}

Participatory mapping and GPS tracking diverged in terms of which fishers from which villages travel the longest distances. This could indicate that the GPS tracking method failed to capture these longest distances traveled, either because they are rare among fishers or because participants refrained from taking the GPS on these longer trips. This is possible because, even though the GPS tracking covered 16 months, the sampling was done to some extent in an opportunistic fashion (within the parameters explained in section "Materials and Methods") because the fishers' willingness to participate in the research varied not only among the villages but also throughout the different seasons. This, together with the difficulties of transportation and the high rate of GPS damage/loss, also led to a low number of routes tracked.

During participatory mapping, informants often had difficulties estimating how far into the mangroves they usually have to walk to fish the crab. For example, even though many informants mentioned the road and the fishing that happens along the road, most of them could not specify how far into the mangroves the fishers go to collect the crab. When distances were estimated, they ranged from "no more than 200 meters" to "approximately two kilometers." The GPS tracking complements this piece of information by showing that fishers are not far from the edge of the mangroves. Sometimes they have to walk a long distance to find what they consider an appropriate site. But walking does not necessarily mean moving away from the border, and they remain close to the edge of the mangrove forest, as also shown by Thies-Albrecht (2016).

Three important limitations of participatory mapping, when used alone, could be identified. Firstly, the delimited fishing grounds are simplified approximations of the many perceptions by fishers of location and designation of those fishing grounds rather than precise, well-delimited areas where fishing occurs during one fishing trip. Secondly, participatory mapping did not give information about the routes, so GPS tracking data were used to reconstruct the movements of fishers. Fishers could have been asked to describe the routes during the participatory mapping. However, this would have required a much better understanding of the maps by the fishers, who would usually only name two points, village of origin of fishers and fishing 


\section{participatory mapping}

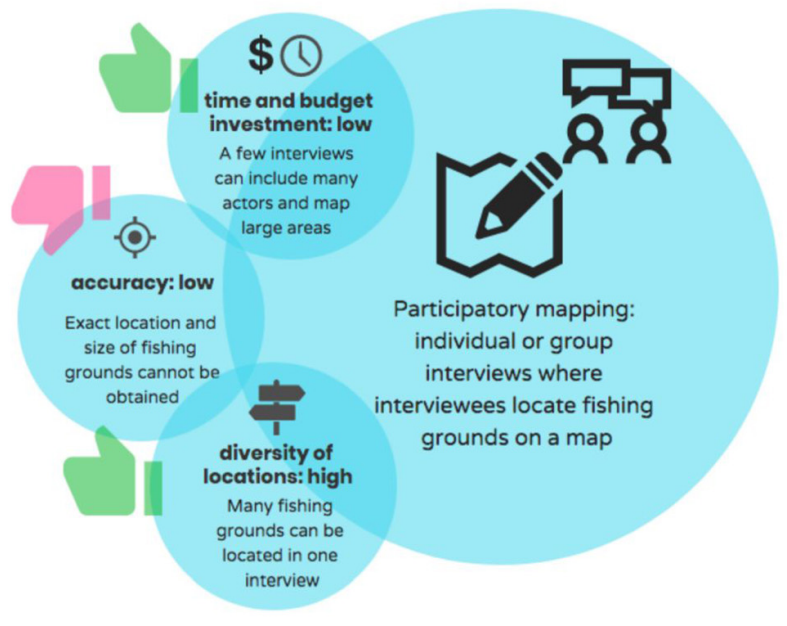

\section{VS. GPS tracking}

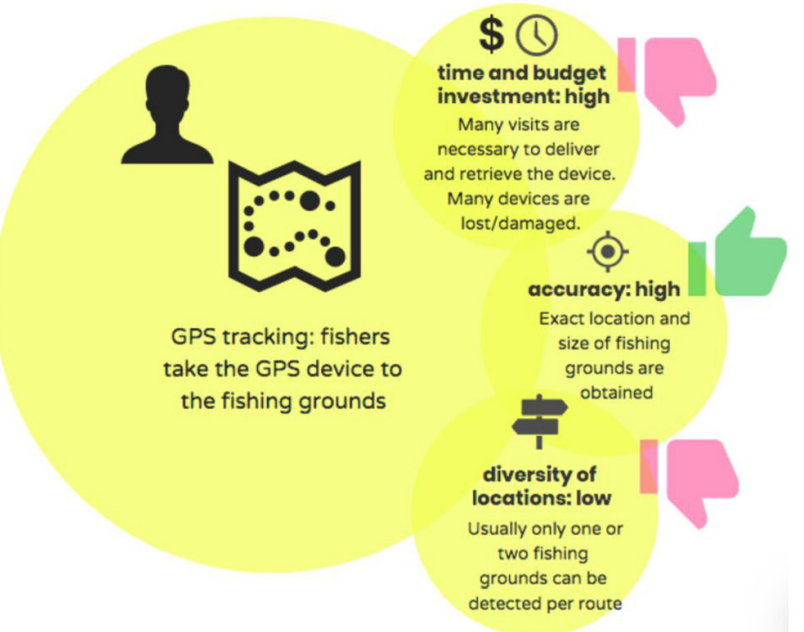

FIGURE 2 | Comparison between participatory mapping and GPS tracking.

ground. Additionally, asking for the entire route to fishing grounds would have been highly time-consuming. Regarding the participatory mapping, only the fishing ground information that was simultaneously provided along with the fishing village was selected for the analyses, so that fishers' village and municipality of origin could be established and compared to the GPS tracking data. Thirdly, informants suggested to ground check the location of the fishing grounds mentioned because they were unsure about some of them on the map. For this purpose, on-site boat visits were undertaken to confirm the location of places mentioned during interviews and focus group discussions. Ground-truthing, as well as consultation of previous studies, was done to complement interviews.

We compared both data collection methods (Figure 2) and analyzed the data produced by the combination of these methods (Figure 3). GPS tracking, for example, can help elucidate (1) the routes traveled by fishers, (2) whether they use one or more fishing grounds per route, and (3) how far they enter the mangroves. Participatory mapping, on the other hand, reveals the size of the smallest use areas to which users have attributed a local name. This has some advantages, such as (1) it allows the investigation of patterns by villages that could not participate in the research; and (2) it gives insights on possible conflicts and on how fishers perceive the behavior of other users. With the participatory mapping, fishers and other users mentioned fishing patterns of other users, which contributes to increased diversity of locations identified. The GPS tracking complemented these data by systematically covering different fishers who use a variety of transportation methods. This allows for a clearer picture of the spatial dynamics patterns and for a differentiation of user types.

One challenge encountered in combining GPS tracking and participatory mapping information is the difference in fishing ground sizes: a mean of $11.03 \mathrm{~km}^{2}(\mathrm{SD}=9.05 ; \min =0.27$, $\max =36.02)$ for the participatory mapping grounds and of $0.0212 \mathrm{~km}^{2}$ for the GPS tracking grounds from a previous study (Thies-Albrecht, 2016). The average fishing ground from participatory mapping was approximately 520 times larger than the GPS-measured fishing area. Even though GPS tracking grounds could be incorporated into the participatory mapping data, some loss of detailed information was observed, for instance, on where exactly fishers find the crabs and on whether they visit more than one fishing ground per route. This difference could be lessened, for instance, by accompanying fishers in the trips to the mangroves to observe how far into the mangroves these fishers go (i.e., distance to the edge of the forest). However, this apparent mismatch in fishing ground size also relates to the definition of "fishing ground" in terms of (1) what is known as a "fishing ground" (sometimes referred to as "fishing territory") for an extended period (and usually named by local users) and the (2) the actual area (or "fishing point") used by fishers during one fishing trip. How to approach this difference will depend largely on the purpose of the method combination. When zoning a co-managed PA, for example, the delimitation of fishing territories would probably be more useful to implement spatial management strategies.

Informants tended to mention more about the PA to which they are more closely related, and there were a higher number of informants in the municipality of Bragança than in Tracuateua ( 87 and 48 , respectively). Therefore, the higher use frequency and diversity of fishing grounds in the Bragança PA could be related to the larger population there. However, during the interviews, informants also frequently associated the higher user intensity in Bragança to the processing plants in this municipality. It is also crucial to highlight the different economic aspects between these cities. 


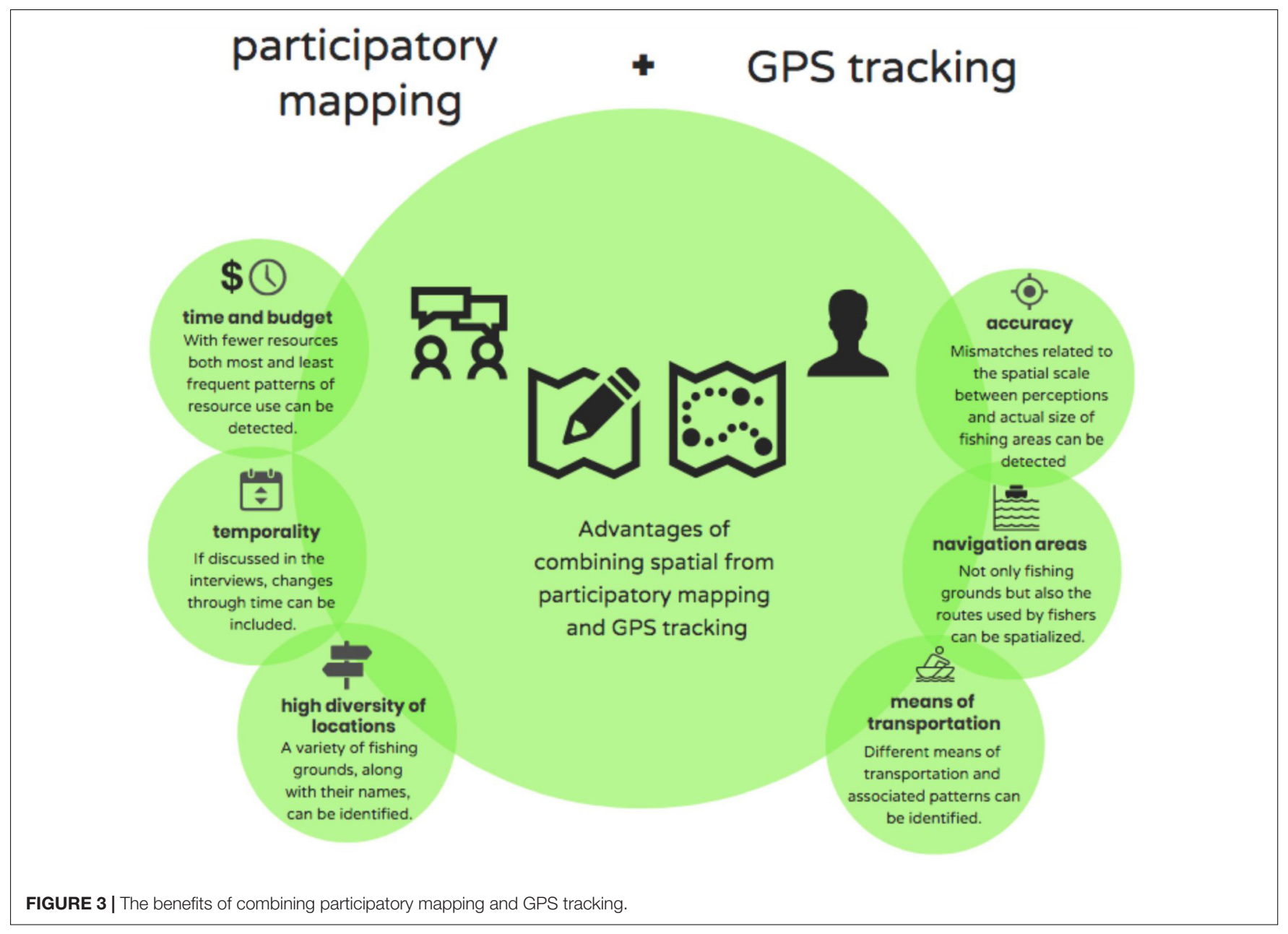

\section{Using Reconstructed Routes to Calculate Distance to Fishing Grounds}

Combining the participatory mapping (40 grounds) and the GPS tracking data (14 grounds) (Figure 4), a total of 45 different fishing grounds were identified in the region, with a mean fishing ground area of $11.03 \mathrm{~km}^{2}(\mathrm{SD}=9.05 ; \min =0.27$, $\max =36.02)($ Table 2).

The distances between the home village and fishing grounds are significantly longer when recorded via participatory mapping compared to GPS tracking $\left(F_{127}=11.06, p=0.0012\right)$. In fact, the distances recorded via the participatory mapping $(20.85 \pm 14.78 \mathrm{~km})$ were on average nearly twice as long as those recorded via GPS tracking $(11.46 \pm 8.47 \mathrm{~km})$ (Figure 5).

\section{Distance to Fishing Grounds vs. Crab Size}

The relationship between the distances to the fishing grounds and the spatialization of crab size, based on carapace width from Oliveira (2015), was also analyzed. The results revealed a nonsignificant interaction of the terms "method" and "crab size" (LRTmethod*crab: $F_{99}=1.661, p=0.2005$ ), meaning that the effect of crab size on distance was the same for both methods.
The results revealed that crabs tended to be larger if caught farther away from the villages $(p<0.001)$ (Figure 6), regardless of whether the distance was estimated through GPS tracking or participatory mapping $(p=0.07)$.

\section{DISCUSSION}

This study combines GPS tracking data and local knowledge to locate fishing grounds. The advantages and downsides of each method are presented, as well as how their application in conjunction can be performed to generate data to improve the management of fisheries and PAs. For both methods, light is shed on concrete ways to analyze spatial data to understand user behavior, which has been identified as a challenge for participatory mapping (Brown and Kyttä, 2014).

\section{Combining Participatory Mapping and GPS Tracking}

Due to the dispersed nature of crab fishing and precarious investment in technical monitoring, data-poor fisheries settings, such as the mangrove crab fisheries in northern Brazil, can benefit from more research based on combining and comparing data 


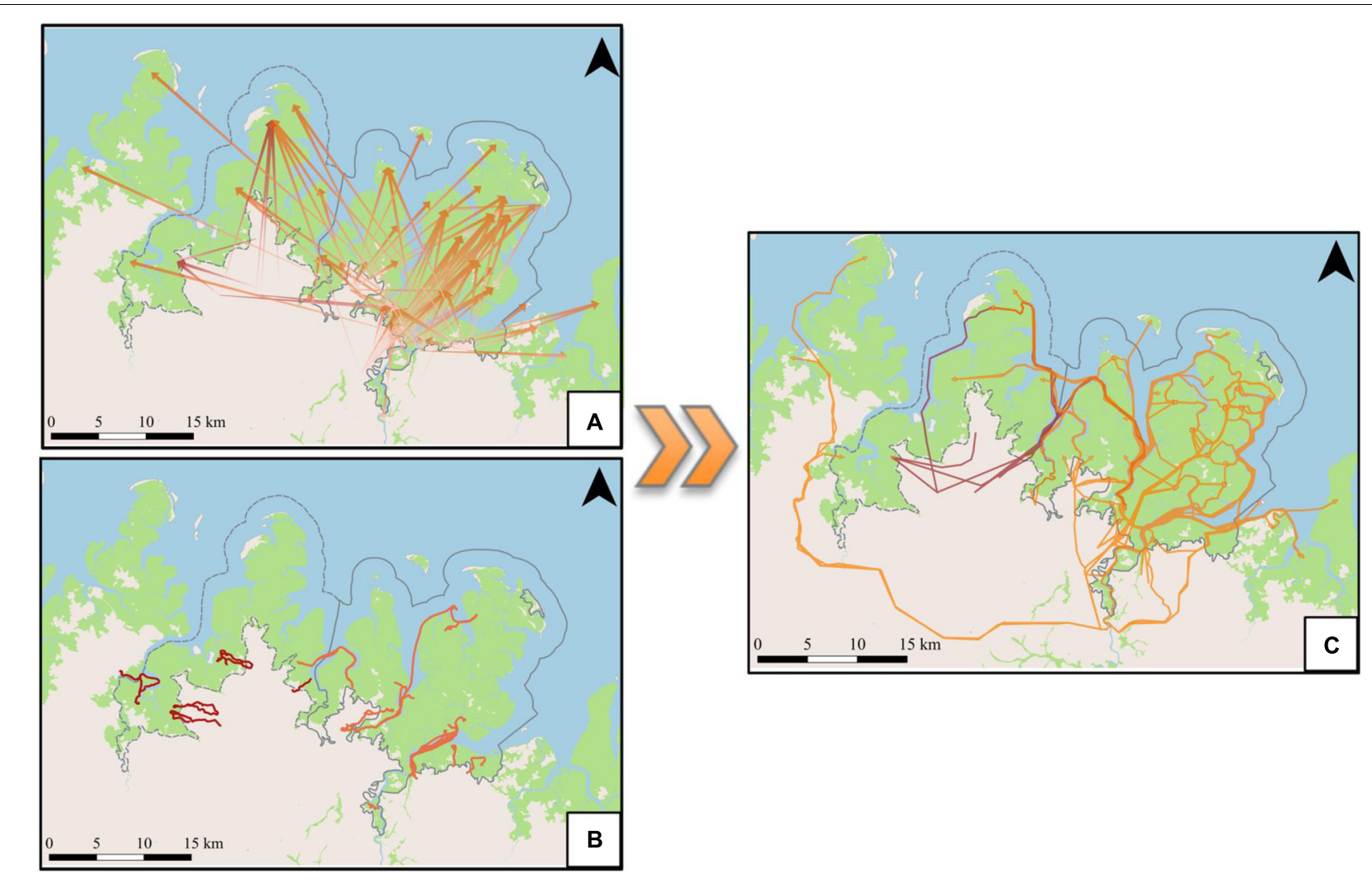

FIGURE 4 | Movements of fishers according to (A) participatory mapping; (B) GPS tracking; and (C) reconstruction combining the two datasets. Movements of fishers from Tracuateua are shown in red, while those from Bragança are shown in orange. The arrow bases in (A) and (C) represent the home villages, and the arrowheads the corresponding fishing grounds. The flows reflect the supply areas and the primary beneficiaries because only the catch is considered in this study, not the entire value chain of the fishing activity.

from various collection methods and knowledge systems. This could be of special use when a small set of rich but laborious-tocollect data, such as from GPS tracking, could feed into an easierto-implement source of data, such as participatory mapping.

Using a combination of data collected by these two different methods, this study shows that both place of origin of the fisher (i.e., fishing village) and method used to identify the fishing grounds (i.e., participatory mapping or GPS tracking) influenced

TABLE 2 | Dataset summary of distances with GPS tracking and participatory mapping.

\begin{tabular}{llc}
\hline & & Distance $(\mathbf{k m})$ \\
\hline GPS tracking & Mean & 11.46 \\
& Standard deviation & 8.47 \\
& Median & 8.99 \\
& Maximum & 24.81 \\
Participatory mapping & Minimum & 1.94 \\
& Mean & 20.85 \\
& Standard deviation & 14.78 \\
& Median & 18.28 \\
& Maximum & 86.81 \\
& Minimum & 1.50
\end{tabular}

the results obtained on distances traveled by the fishers between village and fishing grounds. Regarding place of origin, these results indicate that fishers from certain villages tend to travel further than those from other villages to fish crabs. This will be further explored in an upcoming paper. Regarding the method, results on overall distances were longer by the participatory mapping than by the GPS tracking. These longer distances could be explained by the fact that more distant fishing grounds were mentioned by the fishers in the interviews. These are harder to capture by GPS tracking alone because these trips rarely occur and would have needed a wider and longer GPS tracking effort. The GPS battery might also not hold long enough to have covered the longest trips. Fishers are aware of this constraint and might choose not to take the device on these trips. According to the fishers, the battery would hold for a maximum of about $12 \mathrm{~h}$. The fishers also mentioned during the interviews that they usually stay for at least 2 days when fishing in what they consider to be "very far fishing grounds." Fishers could have deliberately avoided the more distant fishing grounds when they were carrying GPS trackers.

The two methods have been shown to yield complementary information (Wanyonyi et al., 2018). Similar to the results shown here, these authors observed that GPS tracking provides fine-scale spatial and seasonal mapping of fishing activity and 


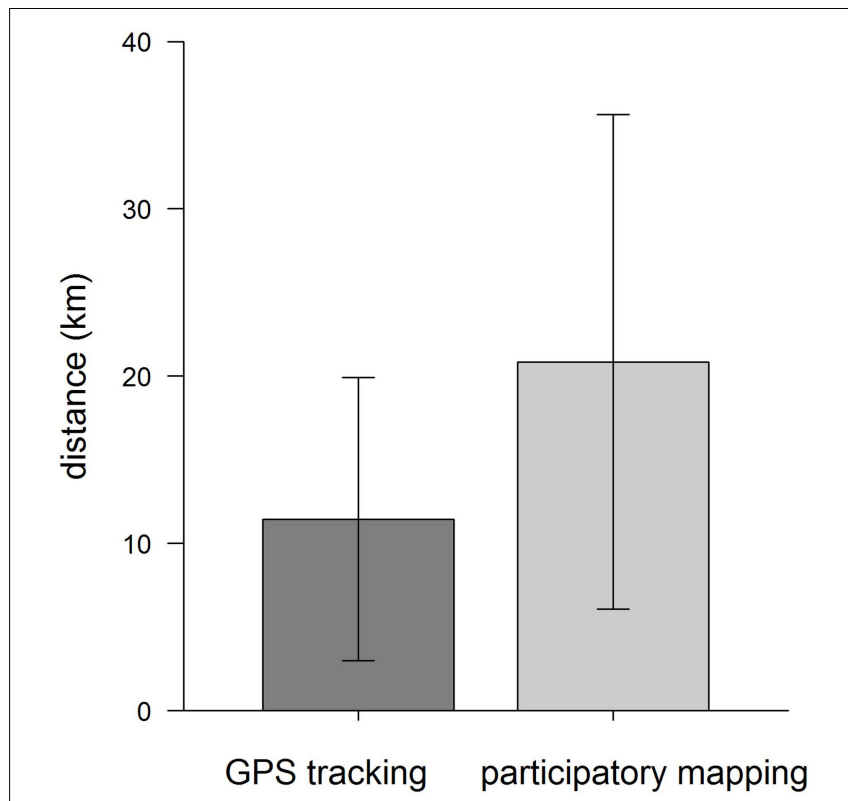

FIGURE 5 | Average distances $( \pm$ SD) recorded via GPS tracking $(n=17)$ and participatory mapping $(n=112)$.

spatial allocation of fishing effort. Having performed tracking for almost one and a half years, seasonal trends could be incipiently identified, which could not have been derived from the participatory mapping. On the other hand, mapping has the advantage of documenting a seascape from the vantage point of fishers (Silvano and Begossi, 2012; Wanyonyi et al., 2018).
The benefits of analyzing spatial aspects of fisheries dynamics and management can be manifold. Adequate consideration of these aspects and the use of the local knowledge of harvesters to complement technical data such as the GPS tracking, as done in this study, can reduce conflicts over the use of resources (De Freitas and Tagliani, 2009). Displaying data using GIS software and employing spatial analysis tools that allow for visualization and pattern recognition is particularly effective when working with local people because visual aids help to bridge the divide between local knowledge and technical knowledge (Aswani and Lauer, 2006).

Actors and knowledge systems that create and underpin data are often excluded from decision-making, especially marginalized fishers, such as crab harvesters, which often remain at the edge of co-managed small-scale fisheries. Thus, there is a need to develop functioning mechanisms to engage and legitimate synergies between knowledge systems in a transparent and constructive way (Reid et al., 2006). Affordable and transparent participation mechanisms and knowledge integration methods, like the method match proposed here, should be further investigated and incentivized, for instance, by special issues in method-oriented journals or calls for grant proposals. This combination of methods could serve to voice desires and needs of often marginalized populations and include them in management processes, especially in PAs where people live or extract resources that are essential to their livelihoods. The combination of methods also enables listening to local stakeholders through participatory mapping and a deeper understanding of their behavior patterns with GPS tracking.

Challenges related to participatory mapping and GPS tracking of individual fishing trips remain to be tackled. For example, it is important to have clarity of purpose for the participatory

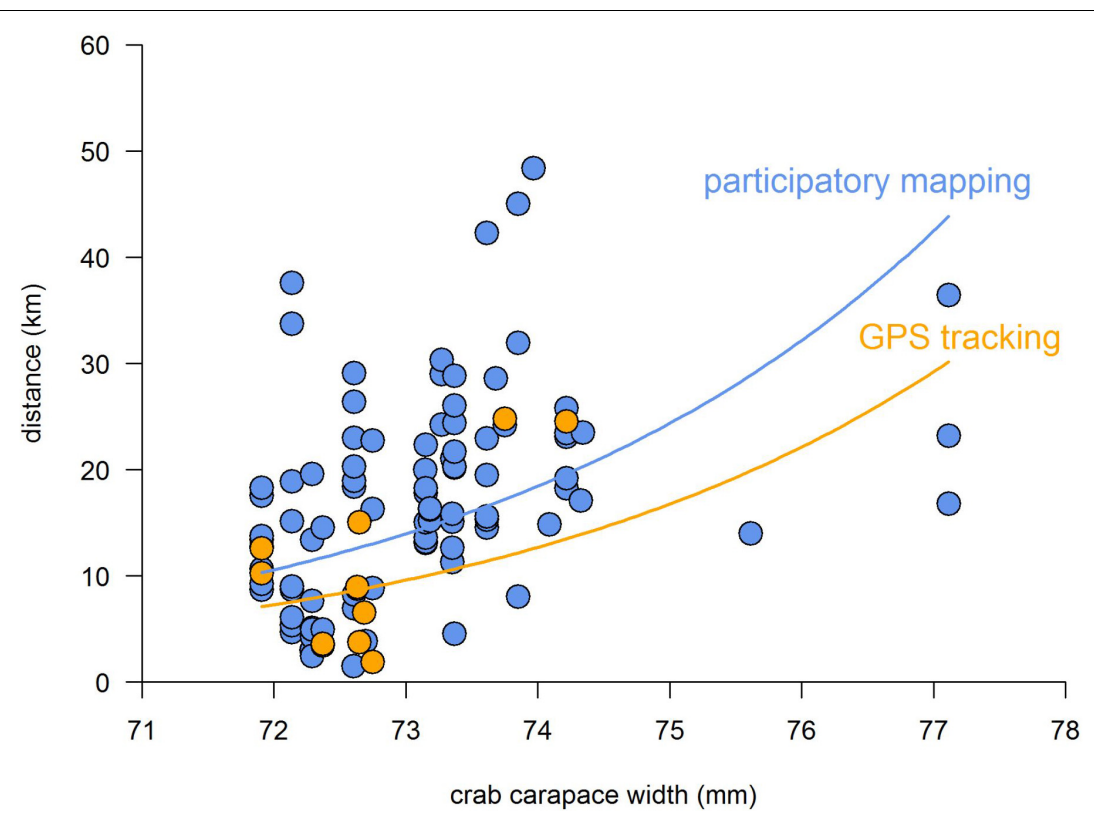

FIGURE 6 | Relationship ( $p<0.001)$ between crab sizes and distances traveled by fishers recorded via GPS tracking $(n=11)$ and participatory mapping $(n=92)$, with no significant difference between the two methods ( $p=0.07)$. 
mapping process, building trust with participants in the process, and understanding the power dynamics of the participatory mapping process (Brown and Kyttä, 2014). These same barriers seem to apply to GPS tracking and are not solved by a multimethod approach to research or management, as proposed here.

\section{Crab Size and Distances Traveled}

In the study region, the results revealed that crabs tend to be larger if caught farther away from the villages where fishers reside. Other studies have also shown this relationship, even though they used distance to "markets" instead of distance to "home villages" (Cinner and McClanahan, 2006; Brewer et al., 2013). In our case, the villages are usually the primary marketplaces, after crabs are brought in from the mangroves. In this region, there are exploitative patron-client relationships, where patrons generally control market access for most fishers who reside remotely and cannot transport crabs to market independently (Partelow et al., 2018). Therefore, proximity to villages/markets help explain fisheries exploitation level and need to be considered in the development of resource-management strategies (Cinner and McClanahan, 2006; Brewer et al., 2013).

Further aspects still need to be examined regarding the status of the crab fisheries. There is a need to consider, for example, the emergence of processing plants of crab meat since the last comprehensive stock assessments and a possible increase in fishing effort and/or the use of distant fishing grounds outside the limits of the fishers' home PA. Concerns regarding the ecological and social sustainability of the crab fisheries in the study site call for inter- and transdisciplinary efforts to establish relevant fishery management priorities with the active participation of the centrally affected stakeholders (Glaser and Diele, 2004). This multi-method approach, if expanded, can shed light on these changes in spatial dynamics while promoting enhanced participation of local users in research, monitoring, and policy development.

In a future publication, the introduced combination of methods is further employed to assess whether and under what circumstances fishers (1) travel long distances to find larger crabs, (2) systematically target areas with larger crabs, and/or (3) prefer areas with easier access but with smaller crab sizes. With a focus on optimal foraging as a fishing strategy and a deeper look into the details of the local crab fisheries, this next study will also search for possible drivers of observed patterns, i.e., the factors that influence fishers' decision-making in terms of their movements in search for the crabs.

\section{CONCLUSION}

A multi-method approach is used to elucidate whether and how distance traveled by the fishers and crab size are related. The advantages and downsides of each method are presented, as well as how their application in conjunction can be performed to generate data for improved management of fisheries and marine PAs.

Even though the combination of participatory mapping and GPS tracking is especially useful for difficult-to-access mangrove areas, it could also be used in other ecosystems. The methods applied in this study can be considered a good model for studies in other contexts of marine spatial planning and small-scale fisheries. Regarding crab size and distance, crabs tended to be larger if caught further away from the villages.

Firstly, in a context of scarce biological and ecological knowledge about coastal fisheries to support management decisions, like on the coast of Brazil's Amazonian region, this study provides a local knowledge database about crab fisheries. The methods presented here can complement effort and catch monitoring techniques. Depending on the issue at hand, one or the other method could be applied. For instance, when establishing PA zones, the level of accuracy of fishing ground location identified by GPS tracking would probably not be easily recognized by fishers, which could cause confusion among users. Participatory mapping, linked to other criteria, could be a better option for managers.

Beyond data generation, this multi-method approach has the potential of increasing stakeholder participation in research and management. If conservation is to play a role in safeguarding people's livelihoods as well, it needs a pluralist approach to knowledge and greater deliberation and inclusion of actors in decision-making processes (Brown, 2013). Considering the comanagement scheme and the sustainable-use regime of the extractive reserves in the mangrove regions of northeastern Pará, this pluralistic approach is much needed. Further translation into policy and incorporation of different knowledge systems into management is essential. Considering the socio-economic circumstances, however, the strengthening of cooperation for conservation is key to guaranteeing the sustainability of the crab fisheries in the Amazonian mangroves.

The approach presented in this paper contributes with an option for improving spatial planning for crab conservation, including the livelihoods that associated crab fisheries sustain, by merging local and technical knowledge to fill gaps in limited small-scale fisheries data.

\section{DATA AVAILABILITY STATEMENT}

The datasets presented in this study can be found in online repositories. The datasets also contain detailed information on the methodology, including explanations regarding possible concerns related to the handling and publication of the data presented here. The names of the repository/repositories and accession number(s) can be found below: https://www.seanoe. org/data/00516/62732/.

\section{ETHICS STATEMENT}

Ethical review and approval was not required, at the time of the beginning of this research project, for the study on human participants in accordance with the local legislation and institutional requirements. Written informed consent for participation was not required for this study in accordance with the national legislation and the institutional requirements. 


\section{AUTHOR CONTRIBUTIONS}

RB was responsible for the conceptualization, data curation, the funding acquisition, the field work, the development of the methodology, the project management, the validation, verification, and visualization of the data, and the writing of the manuscript. IALE contributed with the writing, reviewing, and editing of the manuscript. RSLB helped with the conceptualization, the funding acquisition, the project administration, as well as the project supervision, and the writing, reviewing, and editing of the manuscript. KB collaborated with the data curation, the statistical analyses, the methodology, the software used, and with the validation, verification, and visualization of the data. MG and PFML were co-responsible for the research project supervision, and the writing, reviewing, and editing of the manuscript. All authors contributed to manuscript revision, read, and approved the submitted version.

\section{FUNDING}

RB was grateful to the Brazilian National Council for Scientific and Technological Development - CNPq for the scholarship to perform the doctoral research (process 290055/2014-8) and

\section{REFERENCES}

Abdala, G., Saraiva, N., and Wesley, F. (2012). Plano de Manejo da Reserva Extrativista Marinha de Caeté-Taperaçu (PA). Bragança: Instituto Chico Mendes de Conservação da Biodiversidade.

Aswani, S., and Hamilton, R. J. (2004). Integrating indigenous ecological knowledge and customary sea tenure with marine and social science for conservation of bumphead parrotfish (Bolbometopon muricatum) in the Roviana Lagoon, Solomon Islands. Environ. Conserv. 31, 69-83.

Aswani, S., and Lauer, M. (2006). Incorporating fishermen's local knowledge and behavior into Geographical Information Systems (GIS) for designing marine protected areas in Oceania. Hum. Organ. 65, 81-102. doi: 10.17730/humo.65. $1.4 \mathrm{y} 2 \mathrm{q} 0 \mathrm{vhe} 4130 \mathrm{n} 0 \mathrm{uj}$

Borges, R. (2020). Assessing the Spatial Management of Mangroves and SmallScale Fisheries in Protected Areas on the Brazilian Amazon Coast. Ph.D. thesis. Bremen: University of Bremen. Available online at: https://media.suub.unibremen.de/handle/elib/1746

Brewer, T. D., Cinner, J. E., Green, A., and Pressey, R. L. (2013). Effects of human population density and proximity to markets on coral reef fishes vulnerable to extinction by fishing. Conserv. Biol. 27, 443-452.

Brown, G. (2013). The relationship between social values for ecosystem services and global land cover: an empirical analysis. Ecosyst. Serv. 5, 58-68. doi: 10.1016/j.ecoser.2013.06.004

Brown, G., and Kyttä, M. (2014). Key issues and research priorities for public participation GIS (PPGIS): a synthesis based on empirical research. Appl. Geogr. 46, 122-136. doi: 10.1016/j.apgeog.2013.11.004

Campos-Silva, J. V., and Peres, C. A. (2016). Community-based management induces rapid recovery of a high-value tropical freshwater fishery. Sci. Rep. 6:34745. doi: 10.1038/srep34745

Cinner, J. E., and McClanahan, T. R. (2006). Socioeconomic factors that lead to overfishing in small-scale coral reef fisheries of Papua New Guinea. Environ. Conserv. 33, 73-80. doi: 10.1017/S037689290600 2748

Cohen, M. C. L., Lara, R. J., Szlafsztein, C., and Dittmar, T. (2004). Mangrove inundation and nutrient dynamics from a GIS perspective. to the Rufford Foundation (20310-1) for a small grant that contributed to the fieldwork. We would like to thank the University of Bremen for funding the open-access publication of this manuscript.

\section{ACKNOWLEDGMENTS}

We are grateful to the participants who shared their knowledge and/or were willing to take the GPS devices to the mangrove, as well as to the assistants who helped us during the fieldwork. We are also grateful to MSc. Andrés Alegría, who performed the initial map preparation and design. We also appreciate the support by GLOMAR - Bremen International Graduate School for Marine Sciences, University of Bremen, Germany and are thankful to the GLOMAR Theme D members, who provided input on the manuscript. We are grateful for the comments and improvements suggested by Matthias Wolff. We also thank the University of Bremen and Christof Dieterle for the help with language editing and proofreading of this manuscript. Most importantly, we are deeply grateful to the research participants and collaborators, who helped design and enriched this research with their local knowledge of the area studied. This manuscript is largely based on RB's doctoral thesis (Borges, 2020).

Wetl. Ecol. Manag. 12, 81-86. doi: 10.1023/b:wetl.0000021668.254 45.41

Cohen, Y., and Cohen, J. Y. (2008). Statistics and Data with R: An Applied Approach Through Examples. Chichester: John Wiley \& Sons, Ltd.

Costa, J. S. P., Bentes, A. B., Cruz, P. A. P., Pereira, L. J. G., Fernandes, S. C. P., Fontes, V. B., et al. (2013). Produção e Socioeconomia do Sistema Caranguejouçá em Unidade de uso Sustentável da Costa Norte do Brasil. Available online at: http://www.repositorio.ufc.br/handle/riufc/28982 (accessed August 15, 2021).

da Rocha Araújo, A. R. (2006). Fishery Statistics and Commercialization of the Mangrove Crab, Ucides cordatus (L.). Bragança-Pará-Brazil. Ph.D. thesis. Bremen: University of Bremen.

Damasio, L., de, M. A., Lopes, P. F. M., Guariento, R. D., and Carvalho, A. R. (2015). Matching fishers' knowledge and landing data to overcome data missing in small-scale fisheries. PLoS One 10:e0133122. doi: 10.1371/journal.pone. 0133122

De Freitas, D. M., and Tagliani, P. R. A. (2009). The use of GIS for the integration of traditional and scientific knowledge in supporting artisanal fisheries management in southern Brazil. J. Environ. Manag. 90, 2071-2080. doi: 10.1016/j.jenvman.2007.08.026

Diniz, C., Cortinhas, L., Nerino, G., Rodrigues, J., Sadeck, L., Adami, M., et al. (2019). Brazilian mangrove status: three decades of satellite data analysis. Remote Sens. 11:808. doi: 10.3390/rs11070808

do Vale Oliveira, M., and de Brito Alves, A. (2021). Saberes e práticas socioambientais na pesca artesanal do caranguejo-uçá na amazônia bragantina (Pontinha do Bacuriteua-PA). Nova Rev. Amazôn. 9, 111-130. doi: 10.18542/ nra.v9i1.10033

Domingues, D. (2008). Análise do Conhecimento Ecológico Local e do Sistema Produtivo Como Subsídio para Gerar Instrumentos de Gestão da Atividade de Exploração do Caranguejo-uçá nos Manguezais da Reserva Extrativista Marinha Caeté-Taperaçu, Bragança-PA. Bragança: Universidade Federal do Pará.

Fulton, E. A., Punt, A. E., Dichmont, C. M., Harvey, C. J., and Gorton, R. (2019). Ecosystems say good management pays off. Fish Fish. 20, 66-96.

Giri, C., Ochieng, E., Tieszen, L. L., Zhu, Z., Singh, A., Loveland, T., et al. (2011). Status and distribution of mangrove forests of the world using earth observation 
satellite data: status and distributions of global mangroves. Glob. Ecol. Biogeogr. 20, 154-159. doi: 10.1111/j.1466-8238.2010.00584.x

Glaser, M. (2003). Interrelations between mangrove ecosystem, local economy and social sustainability in Caeté Estuary, North Brazil. Wetl. Ecol. Manag. 11, 265-272.

Glaser, M., and Diele, K. (2004). Asymmetric outcomes: assessing central aspects of the biological, economic and social sustainability of a mangrove crab fishery, Ucides cordatus (Ocypodidae), in North Brazil. Ecol. Econ. 49, 361-373. doi: 10.1016/j.ecolecon.2004.01.017

Gomes, J. L. S. (2018). Cadeia Produtiva do Caranguejo-uçá (Ucides Cordatus Linnaeus, 1763) no Município de Bragança, Nordeste Paraense, Costa Amazônica Brasileira. Bragança: Universidade Federal do Pará.

Goodman, L. A. (1961). Snowball sampling. Ann. Math. Stat. 32, 148-170.

Hall, S. J., Hilborn, R., Andrew, N. L., and Allison, E. H. (2013). Innovations in capture fisheries are an imperative for nutrition security in the developing world. Proc. Natl. Acad. Sci. U.S.A. 110, 8393-8398. doi: 10.1073/pnas. 1208067110

Hayashi, S. N. (2018). Uso e Conservação dos Manguezais na Costa Amazônica Brasileira: uma Abordagem a Partir de Sensoriamento Remoto. Doctoral thesis. Belém: Universidade Federal do Pará.

IBGE (2019a). Base de Informações Sobre os Povos Indígenas e Quilombolas. Available online at: https:/www.ibge.gov.br/geociencias/organizacao-doterritorio/tipologias-do-territorio/27480-base-de-informacoes-sobre-ospovos-indigenas-e-quilombolas $?=\& \mathrm{t}=$ downloads (accessed February 16, 2021).

IBGE (2019b). Perfil das Cidades: Bragança. Available online at: https://cidades. ibge.gov.br/brasil/pa/braganca/panorama (accessed April 27, 2019).

ICMBio (2004). Centro de Pesquisa e Gestão de Recursos Pesqueiros do Litoral Norte (CEPNOR). Belém. Available online at: https: //www.icmbio.gov.br/cepnor/index.php?id_menu=52 (accessed August 15, 2021).

Kittinger, J. N. (2013). Human dimensions of small-scale and traditional fisheries in the Asia-Pacific Region. Pac. Sci. 67, 315-325. doi: 10.2984/ 67.3 .1

Magalhães, A., da Costa, R. M., da Silva, R., and Pereira, L. C. C. (2007). The role of women in the mangrove crab (Ucides cordatus, Ocypodidae) production process in North Brazil (Amazon region, Pará). Ecol. Econ. 61, 559-565. doi: 10.1016/j.ecolecon.2006.05.013

Maneschy, M. C. (2003). "Sócio-economica: trabalhadores e trabalhadoras nos manguezais," in Os Manguezais da Costa Norte Brasileira, (Fundação Rio Bacanga). Available online at: https://livroaberto.ufpa.br/jspui/handle/prefix/ 591 (accessed August 16, 2021).

Metcalfe, K., Collins, T., Abernethy, K. E., Boumba, R., Dengui, J.-C., Miyalou, R., et al. (2017). Addressing uncertainty in marine resource management; combining community engagement and tracking technology to characterize human behavior. Conserv. Lett. 10, 460-469.

Mills, D. J., Westlund, L., de Graaf, G., Kura, Y., Willman, R., and Kelleher, K. (2011). "Under-reported and undervalued: small-scale fisheries in the developing world," in Small-Scale Fisheries Management: Frameworks and Approaches for the Developing World, eds R. S. Pomeroy, and N. L. Andrew (Wallingford, CT: CABI), 1-15. doi: 10.1079/9781845936075. 0001

Nagelkerken, I., Blaber, S. J. M., Bouillon, S., Green, P., Haywood, M., Kirton, L. G., et al. (2008). The habitat function of mangroves for terrestrial and marine fauna: a review. Aquat. Bot. 89, 155-185. doi: 10.1016/j.ejmech.2020. 112957

Nascimento, W. R., Souza-Filho, P. W. M., Proisy, C., Lucas, R. M., and Rosenqvist, A. (2013). Mapping changes in the largest continuous Amazonian mangrove belt using object-based classification of multisensor satellite imagery. Estuar. Coast. Shelf Sci. 117, 83-93. doi: 10.1016/j.ecss.2012. 10.005

Ogawa, M., da Silva, A. I. M., Ogawa, N. B. P., Maia, E. L., and Nunes, M. L. (2008). Adequações tecnológicas no processamento da carne de caranguejo. Food Sci. Technol. 28, 78-82. doi: 10.1590/S0101-2061200800010 0012

Oliveira, F. (2015). Análise da Percepção dos Extrativistas Estuarino-Costeiros Sobre o Zoneamento da Extração do Caranguejo-uçá (Ucides cordatus) e da Madeira nos Manguezais da RESEX-Marinha Caeté-Taperaçu, Pará, Costa Amazônica Brasileira. Belém: Universidade Federal do Pará.

Oliveira, L., Silveira, B., Santos, J., and Cordeiro, C. (2017). Análise Da Cadeia Produtiva Do Caranguejo-Uçá (Ucides cordatus LINNAEUS, 1763) Na Vila Do Treme, Bragança, Pará. Available online at: https://www.Confea. Org.Br/Sites/Default/Files/Antigos/Contecc2017/Educacao/3_Adcpdcucl1nvdt bp.Pdf (accessed April 30, 2019).

Partelow, S., Glaser, M., Solano Arce, S., Barboza, R. S. L., and Schlüter, A. (2018). Mangroves, fishers, and the struggle for adaptive comanagement: applying the social-ecological systems framework to a marine extractive reserve (RESEX) in Brazil. Ecol. Soc. 23:19. doi: 10.5751/ES-10269-230319

Pennino, M. G., Thomé-Souza, M. J. F., Carvalho, A. R., Fontes, L. C. S., Parente, C., and Lopes, P. F. M. (2016). A spatial multivariate approach to understand what controls species catch composition in small-scale fisheries. Fish. Res. 175, 132-141. doi: 10.1016/j.fishres.2015.11.028

Quantum GIS Development Team (2019). QGIS. Quantum GIS Geographic Information System. Open Source Geospatial Foundation Project. QGIS Association.

Quinn, G. G. P., and Keough, M. J. (2002). Experimental Design and Data Analysis for Biologists. Cambridge: Cambridge University Press.

Reid, W. V., Berkes, F., Wilbanks, T. J., and Capistrano, D. (2006). Bridging Scales and Knowledge Systems: Concepts and Applications in Ecosystem Assessment. Washington, DC: Island Press, 315.

Sganzerla, T. (2017). Are Brazil's Fisheries Heading Towards Collapse? Without Official Data, No One Knows. Available online at: https: //oceana.org/blog/are-brazil\%E2\%80\%99s-fisheries-heading-towardscollapse-without-official-data-no-one-knows (accessed April 30, 2019).

Silvano, R. A., and Valbo-Jørgensen, J. (2008). Beyond fishermen's tales: contributions of fishers' local ecological knowledge to fish ecology and fisheries management. Environ. Dev. Sustain. 10:657. doi: 10.1007/s10668-008-9149-0

Silvano, R. A. M., and Begossi, A. (2012). Fishermen's local ecological knowledge on Southeastern Brazilian coastal fishes: contributions to research, conservation, and management. Neotrop. Ichthyol. 10, 133-147. doi: 10.1590/s167962252012000100013

Sim, J. (1998). Collecting and analysing qualitative data: issues raised by the focus group. J. Adv. Nurs. 28, 345-352. doi: 10.1046/j.1365-2648.1998.00692.x

Smith, H., and Basurto, X. (2019). Defining small-scale fisheries and examining the role of science in shaping perceptions of who and what counts: a systematic review. Front. Mar. Sci. 6:236. doi: 10.3389/fmars.2019.00236

Souza-Filho, P. W. M., Martins, E. S. F., and da Costa, F. R. (2006). Using mangroves as a geological indicator of coastal changes in the Bragança macrotidal flat, Brazilian Amazon: a remote sensing data approach. Ocean Coast. Manag. 49, 462-475. doi: 10.1016/j.ocecoaman.2006.04.005

Souza-Filho, P. W. M., and Paradella, W. R. (2002). Recognition of the main geobotanical features along the Bragança mangrove coast (Brazilian Amazon Region) from Landsat TM and RADARSAT-1 data. Wetl. Ecol. Manag. 10, 121-130.

Spalding, M., Kainuma, M., and Collins, L. (2010). World Atlas of Mangroves. A Collaborative Project of ITTO, ISME, FAO, UNEP-WCMC. London: Earthscan.

Thies-Albrecht, O. (2016). Spatial and Temporal Dispersal of the U. cordatus Crab Fishery in Mangroves Near Bragança, Northern Brazil: Fishers as Optimal Foragers and Resulting Management Applications. Bremen: University of Bremen.

UNEP (2014). The Importance of Mangroves to People: A Call to Action. Cambridge: UNEP World Conservation Monitoring Centre.

Valiela, I., Bowen, J. L., and York, J. K. (2001). Mangrove forests: one of the world's threatened major tropical environments. Bioscience 51, 807-815. doi: 10.1371/journal.pone.0250022

Vandeperre, F., Higgins, R. M., Sanchez-Meca, J., Maynou, F., Goni, R., and MartinSosa, P. (2011). Effects of no-take area size and age of marine protected areas on fisheries yields: a meta-analytical approach. Fish Fish. 12, 412-426. doi: 10.1111/j.1467-2979.2010.00401.x

Wanyonyi, I. N., Macharia, D., Heenan, A., and Mangi, S. C. (2018). Using participatory methods to assess data poor migrant fisheries in Kenya. Hum. Dimens. Wildl. 23, 569-586. doi: 10.1080/10871209.2018.148 8304 
Worm, B., Barbier, E. B., Beaumont, N., Duffy, J. E., Folke, C., Halpern, B. S., et al. (2006). Impacts of biodiversity loss on ocean ecosystem services. Science 314, 787-790. doi: 10.1126/science.1132294

Worm, B., Hilborn, R., Baum, J. K., Branch, T. A., Collie, J. S., Costello, C., et al. (2009). Rebuilding global fisheries. Science 325, 578-585.

Conflict of Interest: The authors declare that the research was conducted in the absence of any commercial or financial relationships that could be construed as a potential conflict of interest.

Publisher's Note: All claims expressed in this article are solely those of the authors and do not necessarily represent those of their affiliated organizations, or those of the publisher, the editors and the reviewers. Any product that may be evaluated in this article, or claim that may be made by its manufacturer, is not guaranteed or endorsed by the publisher.

Copyright (c) 2021 Borges, Eyzaguirre, Sá Leitão Barboza, Boos, Glaser and Lopes. This is an open-access article distributed under the terms of the Creative Commons Attribution License (CC BY). The use, distribution or reproduction in other forums is permitted, provided the original author(s) and the copyright owner(s) are credited and that the original publication in this journal is cited, in accordance with accepted academic practice. No use, distribution or reproduction is permitted which does not comply with these terms. 